\title{
Vasoactive Intestinal Peptide Enhances Its Own Expression in Sympathetic Neurons after Injury
}

\author{
Robert P. Mohney and Richard E. Zigmond \\ Department of Neurosciences, Case Western Reserve University, Cleveland Ohio 44106-4975
}

Neurons in the adult rat superior cervical sympathetic ganglion (SCG) dramatically increase their content of vasoactive intestinal peptide (VIP) and its mRNA after axotomy in vivo and after explantation. Because the VIP gene contains a functional CAMP response element, the effects of cAMP-elevating agents on VIP expression were examined. VIP, forskolin, or isoproterenol increased cAMP accumulation in explanted ganglia. Secretin, a peptide chemically related to VIP, or forskolin increased VIP levels above those seen in ganglia cultured in control medium, whereas treatment with VIP or secretin increased the level of peptide histidine isoleucine $(\mathrm{PHI})$, a peptide coded for by the same mRNA that encodes VIP. VIP or forskolin also increased VIP-PHI mRNA. In contrast, isoproterenol did not alter levels of VIP, PHI, or VIP-PHI mRNA. Although VIP or forskolin increased CAMP levels in both dissociated neurons and in non-neuronal cells, isoproterenol significantly stimulated cAMP accumulation only in the latter. $\mathrm{VIP}_{6-28}$ was an effective antagonist of the actions of exogenous VIP on cAMP and VIP-PHI mRNA in neuron-enriched cultures. When adult SCG explants were cultured in defined medium, endogenous VIP immunoreactivity was released. When VIP $_{6-28}$ was added to such cultures, it significantly inhibited the increase in VIP-PHI mRNA that normally occurs. These data indicate that VIP, or a closely related molecule, produced by adult neurons after injury can enhance the expression of VIP. Such a mechanism may prolong the period during which VIP is elevated after axonal damage. The possibility is also discussed that, because VIP is present in preganglionic neurons in normal animals, its release during periods of increased sympathetic nerve activity could alter VIP expression in the SCG.

Key words: cAMP; isoproterenol; secretin; superior cervical ganglion; sympathetic; vasoactive intestinal peptide; VIP antagonist
The adult rat superior cervical ganglion (SCG) contains low levels of vasoactive intestinal peptide (VIP)- and peptide histidine isoleucine amide (PHI)-like immunoreactivities (IRs) that are localized in nerve processes and a few neuronal cell bodies (Hökfelt et al., 1977; Sasek and Zigmond, 1989; Zigmond et al., 1992). Dramatic increases in VIP-IR occur in SCG neurons, but not in non-neuronal cells, after transection of the postganglionic nerve trunks of the ganglion (Hyatt-Sachs et al., 1993). Axotomized neurons also increase their levels of VIP-PHI mRNA (Hyatt-Sachs et al., 1993; Mohney et al., 1994). These increases in VIP expression have been shown to result, in part, from the production and release of leukemia inhibitory factor (LIF) by non-neuronal cells at the site of nerve injury and within the axotomized ganglia (Rao et al., 1993a; Sun et al., 1994; Sun and Zigmond, 1996).

VIP expression also increases, both at the level of mRNA and peptide, when sympathetic ganglia are placed into explant culture (Zigmond et al., 1992; Mohney et al., 1994). Although this alteration in peptide expression is known to involve LIF (Rao et al., 1993a; Sun et al., 1994), other factors also have been shown to modulate VIP expression in vitro. For example, the increase in

\footnotetext{
Received March 6, 1998; revised April 29, 1998; accepted May 5, 1998.

This research was supported by National Institutes of Health Grant NS12651. We thank Dr. Kumi Nagomoto-Combs for her help.

Correspondence should be addressed to Richard E. Zigmond, Department of Neurosciences, Case Western Reserve University, 10900 Euclid Avenue, Cleveland OH 44106-4975.

Dr Mohney's present address: National Institute of Environmental Health Sciences, P.O. Box 12233, MD F1-01, 111 T. W. Alexander Drive, Research Triangle Park, NC 27709-2233.

Copyright (C) 1998 Society for Neuroscience $0270-6474 / 98 / 185285-09 \$ 05.00 / 0$
}

VIP-IR normally seen in organ culture is partially inhibited by the synthetic glucocorticoid dexamethasone (Rao et al., 1993b) and is increased by depolarizing agents (Sun et al., 1992).

The VIP gene contains a control element capable of regulating VIP transcription in response to cAMP (Fink et al., 1988). cAMP analogs and drugs that elevate intracellular cAMP levels increase VIP gene transcription in bovine chromaffin, PC12, and neuroblastoma cells (Eiden and Hotchkiss, 1983; Hayakawa et al., 1984; Ohsawa et al., 1985; Fink et al., 1988; Tsukada et al., 1995) and increase VIP-IR in cultured sensory neurons (Mulderry, 1993). Stimulation of cultured SCG with VIP or the chemically related peptides secretin or PHI have been shown to increase the accumulation of cAMP (Volle and Patterson, 1982; Ip et al., 1985). Based on these data, the ability of VIP and secretin to enhance VIP expression in the SCG was examined in culture.

Studies on the role of VIP in the SCG have been hampered by the absence of an appropriate VIP antagonist. A previous screen of VIP analogs that act as VIP antagonists in a number of other tissues failed to identify an antagonist that acts on the SCG (Schwarzschild et al., 1989). More recently, $\mathrm{VIP}_{6-28}$ proved to be the most potent of a number of putative VIP receptor antagonists tested for their ability to block VIP-stimulated and cAMPdependent release of amylase from acinar cells (Fishbein et al., 1994). In addition, this truncated form of VIP binds to VIP receptors in transfected chinese hamster ovary cells and inhibits the binding of VIP to these receptors, without itself activating adenylate cyclase (Gourlett et al., 1996). In the present studies, we show that VIP $_{6-28}$ is also an effective VIP antagonist in the SCG, and results obtained using this analog indicate that endogenous 
VIP can participate in a positive feedback loop in injured sympathetic neurons in which it enhances its own expression.

\section{MATERIALS AND METHODS}

Animals. Male Sprague Dawley rats (200-250 gm) and pregnant female rats were purchased from Zivic-Miller (Zelienople Park, PA) and kept on a $12 \mathrm{hr}$ light/dark cycle with ad libitum access to food and water.

Materials. 3-Isobutyl-1-methylxanthine (IBMX) was purchased form Aldrich (Milwaukee, WI); the random-primed DNA-labeling kit, the $\left[{ }^{3} \mathrm{H}\right] \mathrm{cAMP}$ competitive protein binding assay, and the ${ }^{125} \mathrm{I}$-cAMP radioimmunoassay kit were purchased from Amersham (Arlington Heights, IL); nerve growth factor (NGF) was purchased from Austral Biologicals (San Ramon, CA); and VIP, VIP ${ }_{6-28}$, and secretin were purchased from Bachem (King of Prussia, PA). Positively charged nylon membranes, dispase, aprotinin, leupeptin, and phenylmethylsulfonyl fluoride (PMSF) were obtained from Boehringer Mannheim (Indianapolis, IN), forskolin was obtained from Calbiochem (La Jolla, CA), and mouse laminin was obtained from Collaborative Research (Bedford, MA). F-12 nutrient medium and Leibovitz's L-15 medium were purchased from Life Technologies (Gaithersburg, MD), and KT5720 was purchased from LC Laboratories (Woburn, MA). ${ }^{125} \mathrm{I}$-VIP, ${ }^{125} \mathrm{I}$-PHI, all radiolabeled nucleotides, and Reflection autoradiography film were purchased from New England Nuclear Research Products (Boston, MA), and normal rabbit serum, rabbit anti-VIP, and rabbit anti-PHI were purchased from Peninsula Laboratory (Belmont, CA). Isoproterenol hydrochloride was obtained from Pfaltz and Bauer, Inc. (Stamford, CT), bicinchoninic acid protein assay reagents from Pierce (Rockland, IL), SignaTect protein kinase A (PKA) assay system from Promega (Madison, WI), and L-ascorbic acid, $\beta$-D-arabinofuranoside, poly-L-lysine, EDTA, EGTA, and $\beta$-mercaptoethanol from Sigma (St. Louis, MO). QuickHyb was purchased from Stratagene (La Jolla, CA), RNAzol B from Tel-Test, Inc. (Friendswood, TX), and collagenase from Worthington (Freehold, NJ).

Organ culture. Adult rats were killed by decapitation. The SCGs were removed, desheathed, placed in organ culture as previously described (Zigmond and Mackay, 1974), and maintained for 24 or $48 \mathrm{hr}$ in F-12 defined medium equilibrated with $95 \% \mathrm{O}_{2}$ and $5 \% \mathrm{CO}_{2}$. Some ganglia were preincubated for $30 \mathrm{~min}$ in medium containing the VIP receptor antagonist $\mathrm{VIP}_{6-28}$, and then transferred for $24 \mathrm{hr}$ to medium containing both VIP $_{6-28}$ and an agonist. In experiments in which cAMP was to be measured, ganglia were removed from animals and preincubated for 30 min in F-12 medium containing $500 \mu \mathrm{M}$ IBMX to prevent the metabolism of cAMP. Ganglia were then incubated for an additional $30 \mathrm{~min}$ in F-12 medium with IBMX and the compound to be studied. When the action of $\mathrm{VIP}_{6-28}$ was examined, it was added to the medium during the last $5 \mathrm{~min}$ of the preincubation and throughout the incubation. Ascorbic acid $(0.2 \mathrm{mg} / \mathrm{ml})$ was added to cultures containing isoproterenol to retard oxidation of the catecholamine. No significant differences in peptide levels were detected between ganglia maintained in F-12 alone and those cultured in medium containing ascorbic acid.

Cell culture. Cultures of rat sympathetic neurons were prepared as described by Hawrot and Patterson (1979). Neurons from neonatal SCG were enzymatically dissociated with dispase $(5 \mathrm{mg} / \mathrm{ml})$ and collagenase $(1 \mathrm{mg} / \mathrm{ml})$ for $70 \mathrm{~min}$ at $37^{\circ} \mathrm{C}$. To obtain neuron-enriched cultures, cells were preplated for $4 \mathrm{hr}$ on uncoated $35 \mathrm{~mm}$ tissue culture dishes in Leibovitz's L-15 medium containing penicillin $(50 \mathrm{U} / \mathrm{ml})$, streptomycin $(50 \mu \mathrm{g} / \mathrm{ml}), 5 \%$ heat-inactivated rat serum, and NGF (100 $\mathrm{ng} / \mathrm{ml})$. Many non-neuronal cells attached to the plastic dish during this preplating period. The nonadherent cells, which were primarily neurons, were then removed by gentle shaking, collected, and plated onto 24-well poly-Llysine- and laminin-coated dishes. The cells were plated at a concentration of $\sim 40,000$ per milliliter of L-15 medium containing NGF (100 $\mathrm{ng} / \mathrm{ml}$ ) and the cAMP-elevating agent to be studied. Cytosine $\beta$-Darabinofuranoside $(10 \mu \mathrm{M})$ was added to kill dividing cells. Cells were harvested after $48 \mathrm{hr}$. To obtain ganglionic non-neuronal cell-enriched cultures, the less adherent neurons were removed by gentle washing, and the adherent cells were grown in L-15 medium without NGF until sufficient numbers were obtained. The non-neuronal cells were then removed with trypsin-EDTA, replated at $\sim 40,000$ cells per milliliter onto uncoated dishes for $48 \mathrm{hr}$, and then stimulated with various agents.

Radioimmunoassays for VIP and PHI. Peptides were extracted from adult ganglia or from neuron-enriched cultures prepared from neonatal ganglia. VIP-IR was measured by radioimmunoassay as previously described (Hyatt-Sachs et al., 1993). The sensitivity of the VIP assay was $\sim 7 \mathrm{pg} /$ tube. PHI-IR was assayed in a similar manner with an assay kit purchased from Peninsula Laboratories. The sensitivity of the PHI assay was $\sim 40 \mathrm{pg} /$ tube.

Measurement of $c A M P$. cAMP levels in adult SCG explants were measured using a competitive protein binding assay. Ganglia and the medium used to culture them were transferred to microf uge tubes and boiled for $5 \mathrm{~min}$. EDTA was added (final concentration $4 \mathrm{~mm}$ ), and the ganglia were homogenized and lyophilized. The lyophilized samples were reconstituted in Tris-EDTA buffer $(0.05 \mathrm{~m}$ Tris, $\mathrm{pH} 7.5,4 \mathrm{~mm}$ EDTA), and ${ }^{3} \mathrm{H}$-labeled cAMP was added to aliquots of the samples followed by the addition of a cAMP-binding protein. After an incubation period, unbound cAMP was removed by treatment with a charcoal suspension and centrifuged. A sample of each supernatant was counted, and the content of unlabeled cAMP was determined. The sensitivity of this assay was $\sim 50 \mathrm{fmol} /$ tube. cAMP levels in dissociated neonatal SCG cell cultures were measured by ${ }^{125} \mathrm{I}$-cAMP radioimmunoassay. Extracts and cAMP standards were acetylated by treatment with a 1:2 ratio of acetic anhydride and triethylamine for $1 \mathrm{~min}$ to increase the sensitivity of the assay. Using this procedure, about $2 \mathrm{fmol} /$ tube of cAMP could be detected.

Measurement of cAMP-dependent PKA activity. Ganglia were removed from adult rats and either immediately frozen on dry ice or cultured in defined F-12 medium containing $500 \mu \mathrm{M}$ IBMX and the agent to be studied. After $1 \mathrm{hr}$ in culture, ganglia were removed and frozen on dry ice. Individual ganglia were homogenized at $4^{\circ} \mathrm{C}$ with ice-cold extraction buffer containing $25 \mathrm{~mm}$ Tris $\mathrm{HCl}, \mathrm{pH} 7.4,0.5 \mathrm{~mm}$ EDTA, $0.5 \mathrm{~mm}$ EGTA, $10 \mathrm{~mm} \beta$-mercaptoethanol, $1 \mu \mathrm{g} / \mathrm{ml}$ leupeptin, $1 \mu \mathrm{g} / \mathrm{ml}$ aprotinin, and $0.5 \mathrm{~mm}$ PMSF. Lysates were centrifuged for $5 \mathrm{~min}$ at $4^{\circ} \mathrm{C}$ and $13,000 \times g$, and the supernatants were assayed for PKA activity using the SignaTECT PKA assay system. The PKA activity ratio was calculated as the activity in the absence of added cAMP divided by the activity in the presence of $5 \mu \mathrm{M}$ cAMP.

Northern blot analysis. Ganglia were removed from culture, and total RNA was isolated from groups of two SCGs by homogenization in RNAzol B solution. Total RNA was separated on a $1.2 \%$ agaroseformaldehyde gel, blotted onto a positively charged nylon membrane, and UV-crosslinked. Blots were hybridized with cDNA probes for VIP (a gift from Dr. J. S. Fink; Segerson et al., 1989) and glyceraldehyde-3phosphate dehydrogenase (GAPDH; a gift from Dr. J. M. Blanchard; Fort et al., 1985) labeled using a random-primed DNA labeling kit and $\left.{ }^{32} \mathrm{P}\right] \mathrm{dCTP}$. Hybridization was performed in QuickHyb solution at $68^{\circ} \mathrm{C}$ for $1 \mathrm{hr}$ after $15 \mathrm{~min}$ of prehybridization. Blots were washed twice with $2 \times$ SSC containing $0.1 \%$ SDS for $15 \mathrm{~min}$ at room temperature followed by a high stringency wash performed at $58^{\circ} \mathrm{C}$ for 15 min with $0.1 \times \mathrm{SSC}$ containing $0.1 \%$ SDS. After posthybridization washes, the membranes were exposed to a storage phosphor screen overnight, and the data was quantified using a Molecular Dynamics (Sunnyvale, CA) Storm 840 PhosphorImager. The membranes were also exposed to Reflection autoradiography film for visualization. The ratio of the signal of VIP-PHI mRNA to GAPDH mRNA was used to determine changes in peptide mRNA after the various culture treatments. Blots were stripped between hybridizations when necessary.

Statistical analysis. Data are expressed as mean values \pm SEM. Statistical significance was assessed by ANOVA followed by Bonferroni's $t$ test using the InStat program by GraphPad Software (San Diego, CA). $p<$ 0.05 was considered statistically significant.

\section{RESULTS}

\section{Stimulation of ganglionic cAMP levels and protein kinase $A$ activity in short-term cultures}

The ability of VIP, isoproterenol, or forskolin to alter cAMP levels in the rat SCG in vitro was examined in the presence of the phosphodiesterase inhibitor IBMX. Because agonist-induced increases in intracellular cAMP are often rapid and transient, ganglia were incubated for only $30 \mathrm{~min}$ with the agonist before measurement of the cyclic nucleotide. Levels of cAMP were not significantly different in ganglia cultured in defined F-12 medium and in ganglia frozen immediately after being dissected (Fig. 1 $A$ ). Incubation with VIP, isoproterenol, or forskolin (all at $10 \mu \mathrm{M}$ ) increased cAMP levels in the explanted ganglia 8.6-, 10-, and 21-fold, respectively.

The effects of VIP or forskolin on PKA activity were also examined in SCG cultured for $1 \mathrm{hr}$. No significant difference was 


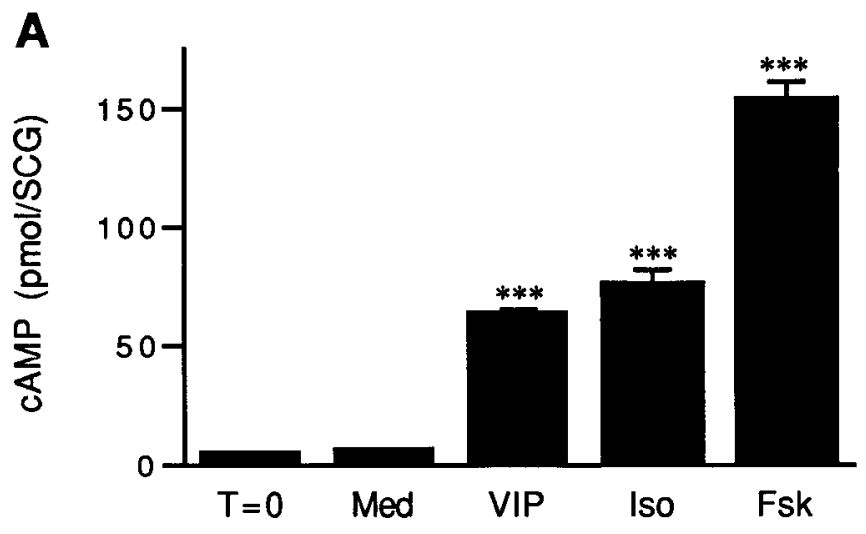

B

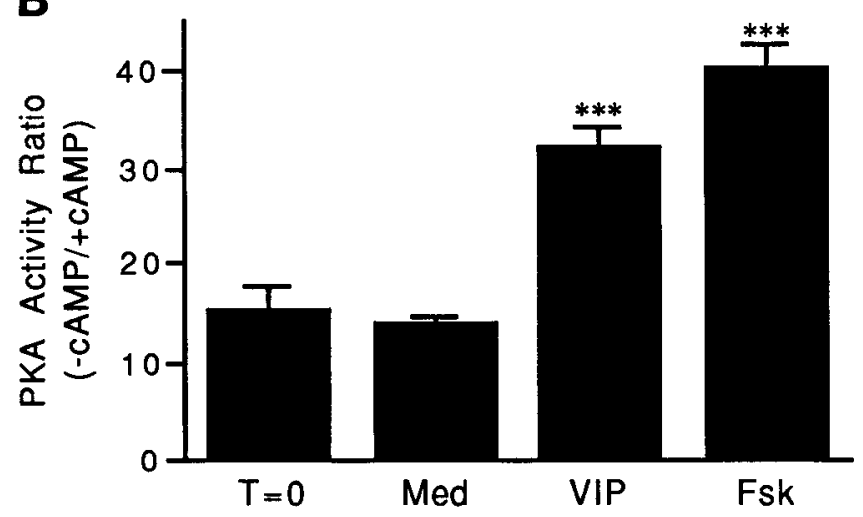

Figure 1. Stimulation of cAMP levels and PKA activity in adult rat SCG. $A$, VIP, isoproterenol, or forskolin increases cAMP levels in SCG in short-term organ culture. Control ganglia $(T=0)$ were removed from animals and processed immediately as described in Materials and Methods. Cultured ganglia were incubated for $30 \mathrm{~min}$ in medium containing IBMX alone (Med) or IBMX together with $10 \mu \mathrm{m}$ VIP (VIP), isoproterenol (Iso), or forskolin (Fsk). Data represent the mean \pm SEM of at least 12 SCGs. $B$, VIP or forskolin increases PKA activity in SCG in short-term organ culture. Control ganglia were removed from animals and frozen until assayed $(\mathrm{T}=0)$. Other SCGs were cultured for $1 \mathrm{hr}$ in defined medium containing IBMX alone (Med) or IBMX together with $10 \mu \mathrm{M}$ VIP $(V I P)$ or forskolin $(F s k)$. The data are expressed as the ratio of PKA activity measured in the absence of added cAMP relative to that in its presence. Data represent the mean \pm SEM of 10 SCGs. ${ }^{* * *} p<0.001$ compared with Med or $\mathrm{T}=0$.

found between PKA activity measured in ganglia frozen immediately after dissection and in ganglia cultured in defined medium containing IBMX (Fig. 1B). In contrast, stimulation of adult explants with VIP or forskolin $(10 \mu \mathrm{M}$ each $)$ caused a significant activation of PKA activity. The addition of VIP to the culture medium resulted in a 2.3 -fold increase in PKA activity over control levels, whereas forskolin, which caused the greatest increase in cAMP levels in the SCG, stimulated PKA activity in the ganglion by 2.9 -fold (Fig. $1 B$ ).

\section{Effects of cAMP-elevating agents on VIP-IR}

To determine whether agents that elevate cAMP levels in the SCG after short-term culture could also alter VIP expression, adult ganglia were cultured for $48 \mathrm{hr}$ in defined medium supplemented with IBMX. Consistent with previous observations, the level of VIP-IR in adult SCG frozen directly after dissection was low, but increased dramatically in culture (Zigmond et al., 1992).
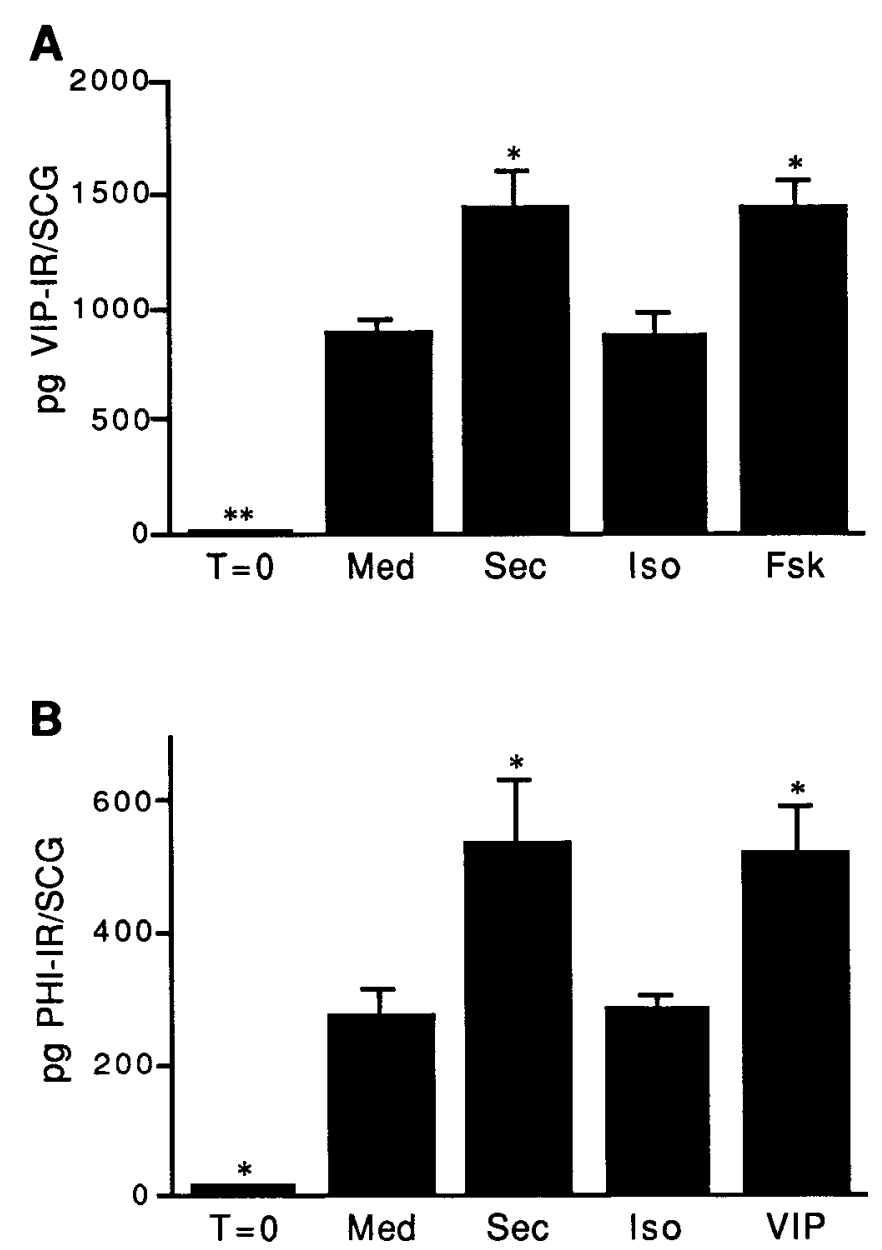

Figure 2. Stimulation of VIP or PHI-IR in cultured adult rat SCG. $A$, Secretin or forskolin, but not isoproterenol, significantly increases VIP-IR in SCG explants. SCGs were removed from animals and either frozen immediately $(T=0)$ or cultured for $48 \mathrm{hr}$ in defined medium containing IBMX alone (Med) or IBMX together with $10 \mu \mathrm{M}$ secretin (Sec), isoproterenol (Iso), or forskolin (Fsk). VIP-IR was determined by radioimmunoassay. $B$, Secretin or VIP, but not isoproterenol, increases PHI-IR in SCG explants. SCGs were treated as described in part A except that the agonists tested were $10 \mu \mathrm{M}$ secretin ( $\mathrm{Sec}$ ), isoproterenol (Iso), or $V I P$, and PHI-IR was measured by radioimmunoassay. For both parts $A$ and $B$, data represent the mean \pm SEM of four ganglia. ${ }^{*} p<0.05$ and $* * p<0.01$ compared with Med.

Because changes in endogenous VIP-IR could not be measured accurately in ganglia cultured in the presence of exogenous VIP, we examined the effect of adding another member of this peptide family, secretin. VIP levels in ganglia cultured in the presence of secretin or forskolin (10 $\mu \mathrm{M}$ each) were elevated by $62 \%$ above that seen in ganglia cultured in control medium alone (Fig. 2A). In contrast to these cAMP-elevating agents, isoproterenol (10 $\mu \mathrm{M}$ ) did not significantly increase VIP levels in the SCG (Fig. $2 A$ ).

\section{Effects of cAMP-elevating agents on PHI-IR}

To determine whether VIP itself altered neuropeptide levels in the SCG, we examined the effects of VIP on PHI, a polypeptide structurally similar to VIP that is coded for by the same mRNA that encodes VIP (Tatemoto and Mutt, 1981; Itoh et al., 1983). Previous studies have shown that PHI and VIP have nearly identical distributions in both the central and sympathetic nervous systems (Hökfelt et al., 1987; Sasek and Zigmond, 1989), and both can be coexpressed in individual neurons of the SCG (Sasek 


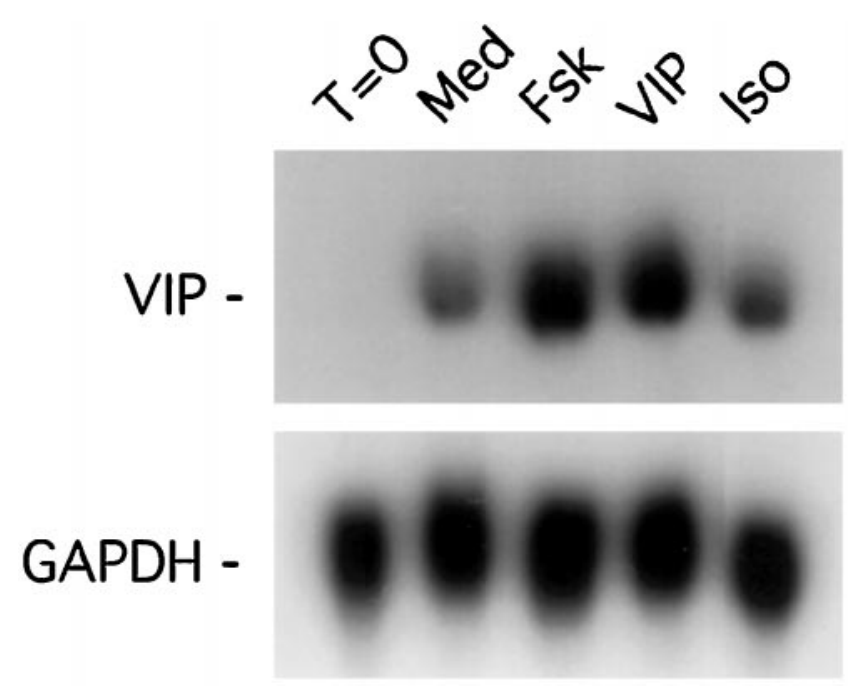

Figure 3. VIP or forskolin, but not isoproterenol, increases the steadystate levels of VIP-PHI mRNA in adult SCG explants. SCGs were removed from the animal and either frozen directly $(T=0)$ or maintained in organ culture for $24 \mathrm{hr}$ in defined medium containing IBMX (Med) or in medium containing IBMX plus $10 \mu \mathrm{M}$ forskolin $(F s k), V I P$, or isoproterenol (Iso). Total RNA was extracted from pairs of ganglia, and Northern blot analyses were performed using radiolabeled cDNA probes for VIP-PHI or GAPDH mRNA.

and Zigmond, 1989). These results suggest that a change in PHI levels can be a useful indicator of a change in the expression of VIP. To examine the effects of cAMP-elevating agents on PHI expression in the SCG, ganglia were cultured for $48 \mathrm{hr}$ in medium alone or in medium containing $10 \mu \mathrm{M}$ VIP, secretin, or isoproterenol, and changes in PHI-IR were measured. Consistent with previous observations (Zigmond et al., 1992), levels of PHI-IR increased significantly in sympathetic ganglia cultured in defined medium alone when compared with levels in ganglia not placed in culture (Fig. 2B). The addition of secretin or VIP to adult explants increased levels of PHI-IR by $90 \%$ when compared with ganglia cultured in defined medium alone (Fig. 2B). As was observed when levels of VIP-IR were measured, levels of PHI-IR in ganglia stimulated with isoproterenol were not significantly different compared with levels in control cultures.

\section{Alterations in VIP-PHI mRNA levels produced by cAMP-elevating agents}

To examine the effect of exogenous cAMP-elevating agents (notably VIP) on VIP-PHI mRNA expression in adult SCG explants, changes in steady-state levels of VIP-PHI mRNA were measured by Northern blot analysis. VIP-PHI mRNA was undetectable in adult rat SCG frozen immediately after dissection. When ganglia were cultured in defined medium for $24 \mathrm{hr}$, however, steady-state expression of VIP-PHI mRNA increased dramatically (Fig. 3). Stimulation of sympathetic ganglia with either $10 \mu \mathrm{M}$ VIP or forskolin for $24 \mathrm{hr}$ resulted in a 2.5 -fold increase in VIP-PHI mRNA compared with control cultures. Similarly, the addition of 10 or $100 \mu \mathrm{M}$ dibutyryl-cAMP to adult SCG explants increased steady-state levels of VIP-PHI mRNA by $\sim 2$ - and 2.5-fold, respectively, compared with ganglia cultured in control medium alone (data not shown). In contrast, the addition of isoproterenol to the culture medium resulted in essentially no increase in VIP-PHI mRNA levels (Fig. 3).

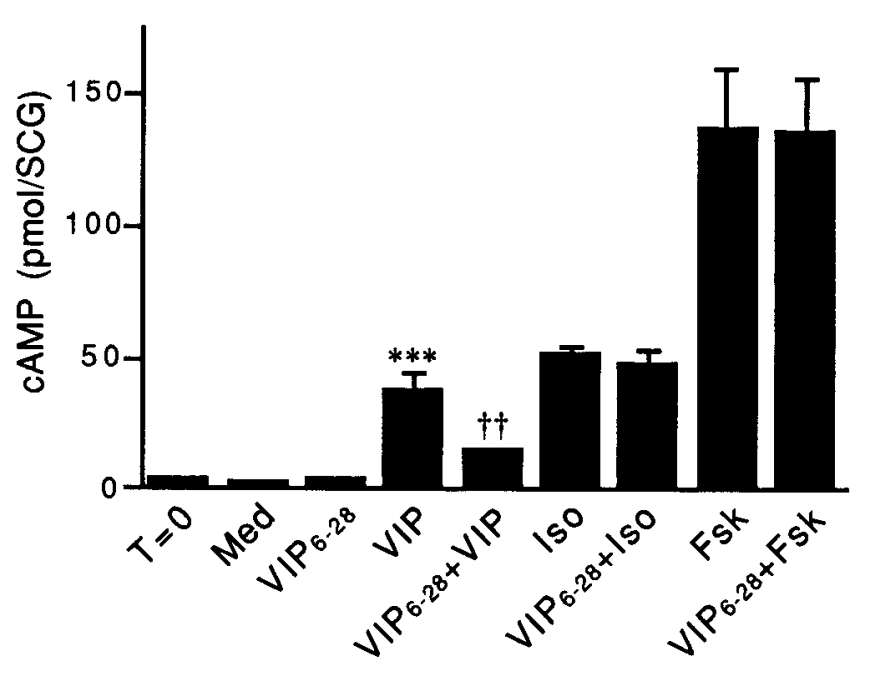

Figure 4. $\mathrm{VIP}_{6-28}$ reduces the increase in cAMP levels measured in adult SCG stimulated with exogenous VIP. Control ganglia were removed from animals and processed immediately as described in Materials and Methods $(T=0)$. After a $30 \mathrm{~min}$ preincubation in the presence of IBMX, cultured ganglia were incubated for an additional $30 \mathrm{~min}$ in medium containing IBMX alone $(\mathrm{Med})$ or together with $10 \mu \mathrm{M}$ VIP $(V I P)$, isoproterenol (Iso), or forskolin (Fsk). To examine the blocking ability of $\mathrm{VIP}_{6-28}$, ganglia were preincubated for $25 \mathrm{~min}$ in medium containing IBMX, transferred to medium containing IBMX and $30 \mu \mathrm{M}$ $\mathrm{VIP}_{6-28}$ for $5 \mathrm{~min}$, and then incubated for an additional $30 \mathrm{~min}$ in medium containing $30 \mu \mathrm{M} \mathrm{VIP}{ }_{6-28}$ alone or together with $10 \mu \mathrm{M} \mathrm{VIP}\left(V I P_{6-28}+\right.$ $V I P)$, isoproterenol $\left(V_{I P} P_{6-28}+I s o\right)$, or forskolin $\left(V I P_{6-28}+F s k\right)$. Data represent the mean \pm SEM of four SCGs. ${ }^{* * *} p<0.001$ compared with $\mathrm{T}=0$, Med, or Ant, and $\dagger \dagger p<0.01$ compared with VIP.

\section{Release of VIP by the SCG in explant culture}

The addition of exogenous VIP to cultures of adult rat SCG increases VIP expression, raising the possibility that VIP produced by sympathetic neurons in culture may be released into the medium and may enhance VIP expression via an autocrineparacrine feedback mechanism. To explore this possibility, individual adult rat SCG were cultured in defined medium containing IBMX and, $48 \mathrm{hr}$ later, the presence of VIP in the ganglion and in the culture medium was measured by radioimmunoassay. Control ganglia contained on average $5.6 \pm 0.7 \mathrm{pg}$ of VIP-IR $(n=6)$, whereas ganglia placed in organ culture for $48 \mathrm{hr}$ contained $800 \pm$ $74 \mathrm{pg}(n=14)$. Moreover, after $48 \mathrm{hr}$ in culture, $270 \pm 84 \mathrm{pg}$ of VIP-IR per SCG $(n=17)$ was detectable in the culture medium, indicating that a significant amount of VIP-IR produced by injured adult sympathetic neurons is released into the culture medium.

\section{VIP $_{6-28}$ is a VIP antagonist in the SCG}

To test whether VIP released by injured sympathetic neurons in culture enhances VIP expression, it was important to find an agent that could specifically interfere with the actions of VIP in the SCG. VIP $_{6-28}$, when added to short-term cultures of adult SCG at a concentration of 10,30 , or $100 \mu \mathrm{M}$, reduced the increase in cAMP levels produced by stimulation with $10 \mu \mathrm{M}$ VIP by 52 , 64 , or $81 \%$, respectively (data not shown). At any of these concentrations tested, $\mathrm{VIP}_{6-28}$ by itself did not alter cAMP levels. In contrast to its ability to reduce the VIP-stimulated elevation in cAMP levels by $64 \%$, the addition of $30 \mu \mathrm{M} \mathrm{VIP}{ }_{6-28}$ to culture medium did not significantly alter cAMP levels measured after stimulation of adult ganglia with either isoproterenol or forskolin (10 $\mu \mathrm{M}$ each; Fig. 4). Similar results on the ability of 


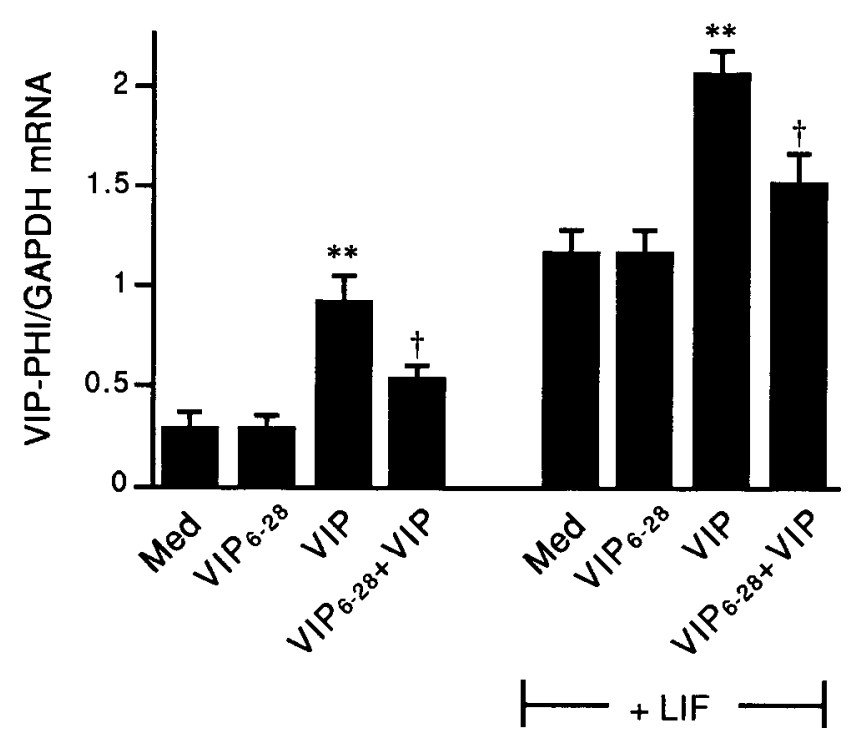

Figure 5. $\mathrm{VIP}_{6-28}$ reduces the effect of VIP but not LIF on VIP-PHI mRNA expression in neuron-enriched cultures. Neuron-enriched cultures were maintained for $48 \mathrm{hr}$ in medium alone $(\mathrm{Med})$ or stimulated with 100 $\mu \mathrm{M} \mathrm{VIP}{ }_{6-28}\left(V_{I P}{ }_{6-28}\right), 10 \mu \mathrm{M}$ VIP $(V I P)$, or both. Other cultures were stimulated with VIP, VIP ${ }_{6-28}$, or both, and also exposed to $10 \mathrm{ng} / \mathrm{ml} \mathrm{LIF}$. Total RNA was isolated and Northern blot analyses were performed. Data represent the mean \pm SEM of five cultures. ${ }^{*} p<0.01$ compared with Med ( \pm LIF, as appropriate); $\dagger p<0.05$ compared with VIP ( \pm LIF, as appropriate).

VIP $_{6-28}$ to block VIP-stimulated increases in cAMP levels were obtained in neuron-enriched and in non-neuronal cell-enriched dissociated cultures (data not shown).

To determine whether $\mathrm{VIP}_{6-28}$ can inhibit the VIP-inducing actions of exogenously added VIP on sympathetic neurons, neuron-enriched cultures derived from neonatal dissociated SCG were isolated and stimulated with VIP $(10 \mu \mathrm{M})$ in the presence or absence of $\mathrm{VIP}_{6-28}(100 \mu \mathrm{M})$. Forty-eight hours later, levels of VIP-PHI mRNA were measured by Northern blot analysis. The neuron-enriched culture preparation offers the advantage that a direct action of $\mathrm{VIP}_{6-28}$ on sympathetic neurons can be examined in the relative absence of ganglionic non-neuronal cells, and, therefore, the effects of non-neuronal cell-derived LIF can be minimized. VIP $_{6-28}$ did not affect VIP-PHI mRNA levels by itself, but it did inhibit, by $60 \%$, the VIP-stimulated increase in VIP-PHI mRNA (Fig. 5).

The effects of VIP and $\mathrm{VIP}_{6-28}$ were also examined in neuronenriched cultures in the presence of exogenous LIF $(10 \mathrm{ng} / \mathrm{ml})$. As expected, LIF by itself increased levels of VIP-PHI mRNA. Additionally, LIF had no apparent effect on the actions of exogenous VIP or the VIP antagonist. Thus, the addition of exogenous VIP to cultures containing LIF increased VIP-PHI mRNA expression further, whereas this VIP stimulation was blocked by $61 \%$ by the addition of the VIP antagonist (Fig. 5).

Having established the efficacy of $\mathrm{VIP}_{6-28}$ as a VIP antagonist in the SCG, the ability of $\mathrm{VIP}_{6-28}$ to inhibit the increase in VIP-PHI mRNA in ganglia cultured in defined medium alone (i.e., medium without exogenous VIP) was examined. As already shown, a pronounced increase in steady-state levels of VIP-PHI mRNA were observed in ganglia cultured in defined medium for $48 \mathrm{hr}$ (Fig. 6). The addition of increasing concentrations of VIP $_{6-28}$ reduced steady-state levels of VIP-PHI mRNA compared with ganglia maintained in defined medium alone. The

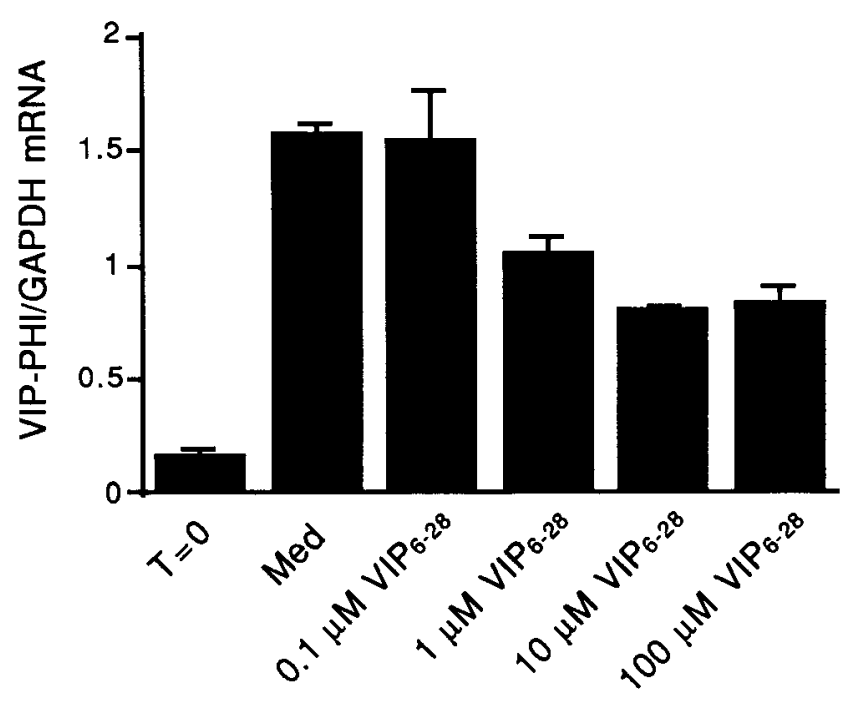

Figure 6. $\mathrm{VIP}_{6-28}$ reduces the elevation in steady-state levels of VIPPHI mRNA that result from placement of adult rat SCG into organ culture for $48 \mathrm{hr}$ in defined medium. Ganglia were removed from the animal and frozen $(T=0)$ or cultured in defined medium alone $(\mathrm{Med})$ or in medium supplemented with $0.1,1,10$, or $100 \mu \mathrm{M} \mathrm{VIP}{ }_{6-28}\left(V_{I P} P_{6-28}\right)$ for $48 \mathrm{hr}$. Total RNA was isolated and examined by Northern blot analyses. Data represent the mean \pm range of two lanes that each contained RNA from two ganglia.

maximal inhibition seen, at concentrations of 10 or $100 \mu \mathrm{M}$ $\mathrm{VIP}_{6-28}$, was $\sim 50 \%$ (Fig. 6). Comparable decreases in VIP-PHI mRNA were produced by the VIP antagonist in ganglia that were maintained for only $24 \mathrm{hr}$ in organ cultures (data not shown).

\section{Isoproterenol increases cAMP levels in cultured non- neuronal cells, but not in neurons}

As noted, isoproterenol increased cAMP levels without increasing VIP or PHI expression. This apparent discrepancy could possibly arise from the $\beta$-adrenergic agonist increasing cAMP levels only in cells within the ganglion that do not express VIP (i.e., nonneuronal cells; Hyatt-Sachs et al., 1993; Mohney et al., 1994). To examine this possibility, neuron-enriched or nonneuronal cell-enriched cultures derived from neonatal rat SCG were stimulated with isoproterenol or other cAMP-elevating agents for $30 \mathrm{~min}$, and then cAMP levels were measured. Stimulation of both neuron-enriched and non-neuronal cell-enriched populations for $30 \mathrm{~min}$ with VIP or forskolin significantly increased cAMP levels compared with levels measured in cells incubated with defined medium alone (Fig. 7 $A, B$; forskolin data not shown). In contrast, stimulation of neuron-enriched cultures with isoproterenol did not produce a significant increase in cAMP levels (Fig. 7A), but did significantly increase cAMP levels in non-neuronal cell-enriched cultures (Fig. 7B).

\section{DISCUSSION}

The ability of cAMP-elevating agents, like forskolin, to increase VIP expression has been demonstrated in a variety of cell types (Eiden and Hotchkiss, 1983; Hayakawa et al., 1984; Ohsawa et al., 1985; Fink et al., 1988; Mulderry, 1993; Tsukada et al., 1987). In the SCG, we find that in addition to forskolin and dibutyrylcAMP, VIP, another cAMP-elevating agent, increases PHI levels and the levels of VIP-PHI mRNA. These effects of VIP on VIP expression in sympathetic neurons can be mimicked by secretin, which also elevates cAMP levels in the SCG (Ip et al., 1985). Interestingly, stimulation of PC12 cells with VIP stimu- 
A

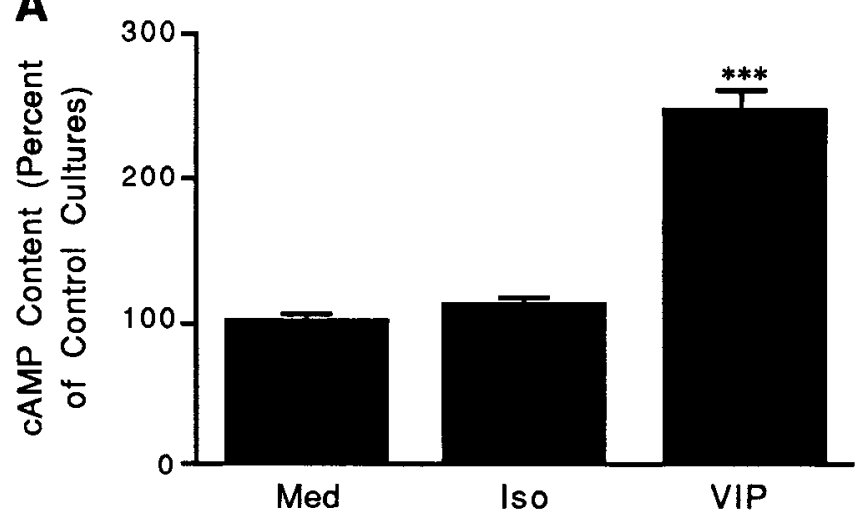

B

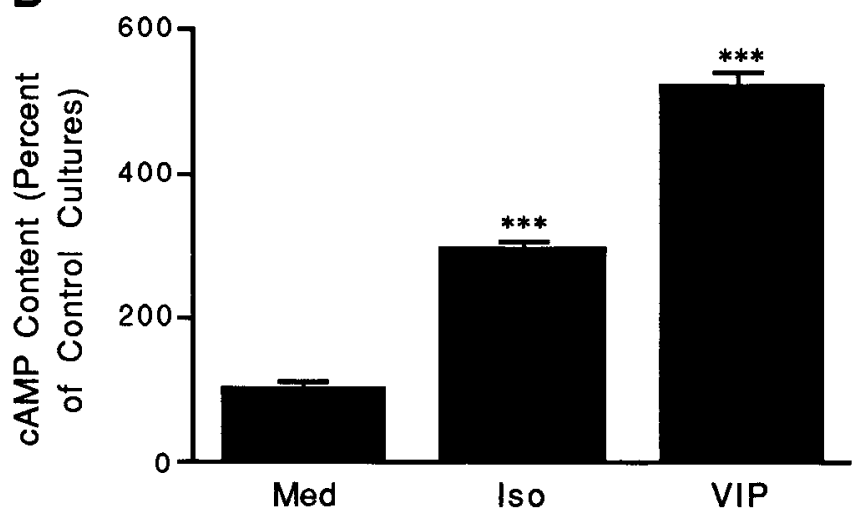

Figure 7. The action of isoproterenol is cell-type specific. $A$, VIP, but not isoproterenol, increases cAMP levels in neuron-enriched cultures. Neonatal SCGs were dissociated and cultured under conditions that favor the survival of neurons but not non-neuronal cells. After $48 \mathrm{hr}$ in culture, neuron-enriched cultures were incubated for $30 \mathrm{~min}$ in medium containing IBMX alone (Med) or IBMX together with $10 \mu \mathrm{M}$ isoproterenol (Iso) or VIP. The content of cAMP is expressed relative to levels measured in cells cultured in control medium alone $(\mathrm{Med})$. Data from several independent experiments were pooled together and represent the mean \pm SEM $(n=27)$. $B$, VIP or isoproterenol increases cAMP levels in non-neuronal cell-enriched cultures. Neonatal SCGs were dissociated and cultured under conditions that favor the survival and proliferation of non-neuronal cells. After $48 \mathrm{hr}$ in culture, non-neuronal cell-enriched cultures were incubated for $30 \mathrm{~min}$ in medium containing IBMX alone (Med) or IBMX together with $10 \mu \mathrm{M}$ isoproterenol (Iso) or VIP. The content of cAMP is expressed relative to levels measured in cells cultured in control medium alone (Med). Data from several independent experiments were pooled together and represent the mean $\pm \operatorname{SEM}(n=12)$. $* * * p<0.001$ compared with Med.

lates PKA activity and increases TH activity, TH mRNA, and NPY mRNA (Roskoski et al., 1989; Wessels-Reiker et al., 1993; Colbert et al., 1994), indicating that the expression of a number of genes in sympathetic neurons can be elevated by this neuropeptide.

In sharp contrast to the other agents tested, isoproterenol did not alter VIP or PHI expression in the SCG, although it increased cAMP content as previously shown (Cramer et al., 1973). Isoproterenol, unlike VIP, secretin, and forskolin, also does not produce an activation of $\mathrm{TH}$ in the SCG, a process that involves cAMP-dependent phosphorylation (Ip et al., 1985; Waymire et al., 1991). One hypothesis that could account for the inactivity of isoproterenol in stimulating either TH activation or VIP expression is that the $\beta$-adrenergic agonist only increases cAMP levels in cells that do not express VIP or TH, possibly glial cells. This hypothesis conflicts with that proposed by Otten et al. (1974) that isoproterenol stimulation occurs in the SCG largely within the principal neurons. These authors based their hypothesis on the finding that the increase in cAMP content in response to isoproterenol was greatly reduced in SCG from animals neonatally treated with the sympathetic neurotoxin 6-hydroxydopamine (Otten et al., 1974). Although their result could reflect a neural site of action of isoproterenol, it could also reflect a change in Schwann cell responsiveness to isoproterenol as a consequence of extensive neuronal loss.

Other studies support our proposal that the main sites of the action of isoproterenol on the SCG are non-neuronal cells. Immunohistochemical studies using an antibody directed against cAMP have shown that a striking increase in cAMP-IR occurs in satellite cells of the SCG when exposed to isoproterenol, with only infrequent and small changes within principal neurons (Ariano et al., 1982). Isoproterenol and other $\beta$-adrenergic receptor agonists have been shown to elevate cAMP in primary cultures of astrocytes (Harden and McCarthy, 1982; Rougon et al., 1983), Schwann cells (Yasuda et al., 1988), and cultured glial cells derived from tumors (Gilman and Nirenberg, 1971). Furthermore, stimulation of adult rat SCG with isoproterenol results in an increased content of proteins specific for glial cells (e.g., S-100 and the $\alpha \alpha$ form of enolase) but does not alter certain neuronspecific markers like neuron-specific enolase (Nagata et al., 1984), although the upstream promoter region of this gene is known to contain a cAMP response element (CRE; Sakimura et al., 1995).

\section{The contribution of LIF and VIP to the induction of VIP-PHI mRNA in culture}

Our data indicate that at least two signals contribute to VIP-PHI mRNA expression in sympathetic neurons in vitro (Fig. 8). One signal, LIF, is known to activate a Janus kinase leading to the phosphorylation of signal transducers and activators of transcription proteins that bind to a cytokine-responsive element in the promoter region of the VIP gene (Symes et al., 1994, 1995). The second signal, VIP itself (and/or a VIP-related peptide), probably acts through elevation of cAMP levels, activation of PKA, phosphorylation of a cAMP response element binding protein (CREB), and the binding of phosphorylated CREB to a CRE in the promoter region of the VIP gene (Fink et al., 1988). The present data using $\mathrm{VIP}_{6-28}$, together with previous studies from our laboratory (Rao et al., 1993a; Sun et al., 1994), support the idea that in SCG explants, LIF increases the expression of VIP, which in turn is released and causes a further increase in VIP expression via a positive feedback mechanism. The fact that, in contrast, $\mathrm{VIP}_{6-28}$ produced no inhibition on VIP expression in neuron-enriched dissociated cultures treated with exogenous LIF probably results from the rapid dilution by the culture medium of the released VIP under these conditions.

In addition to VIP, our data raise the possibility that two other neuropeptides might be involved in regulating VIP expression. Although secretin is more potent than VIP in stimulating cAMP levels in the rat SCG (Ip et al., 1985), and although it causes an elevation of both VIP and PHI-IR, there is currently no evidence that secretin IR is present in the ganglion. A related peptide, pituitary adenylate cyclase-activating peptide (PACAP), however, may be involved in regulating VIP expression. Like VIP, PACAP is present at low levels in the SCG under normal conditions and 


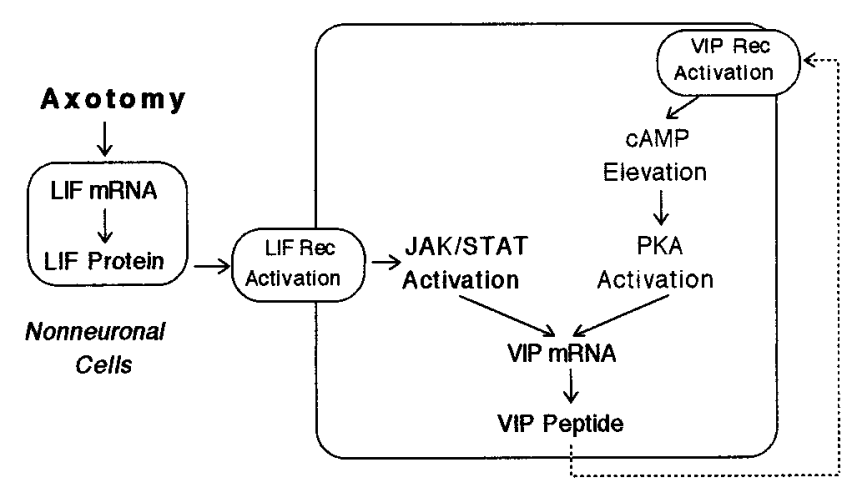

Sympathetic Neuron

Figure 8. Hypothesized mechanism of feedback stimulation of VIP expression in cultured sympathetic ganglia. Under normal conditions, ganglia express only low levels of VIP-PHI mRNA and peptide. When ganglia are placed into explant culture, LIF mRNA (and subsequently, LIF protein) increases in non-neuronal cells as a result of injury-induced factors (Sun et al., 1996). The release of LIF and its binding to receptors on neurons cause the activation of Janus kinases $(J A K)$ and the phosphorylation of signal transducers and activators of transcription (STAT) proteins. Phosphorylated STAT proteins then translocate to the nucleus and bind to and increase the rate of transcription of the VIP gene (Symes et al., 1994, 1995). VIP is released by neurons in culture and binds to VIP $_{6-28}$-sensitive, G-protein-coupled receptors in neurons to elevate cAMP levels. Elevations in cAMP levels activate PKA and lead to increased VIP gene transcription.

at higher levels in culture or after axotomy in vivo (May et al., 1996; R. E. Zigmond and V. May, unpublished observations).

\section{Receptors, second messengers, and cell types involved in the peptidergic regulation of VIP expression}

Signal transduction by VIP and PACAP can occur through at least three distinct receptors. The PACAP1 receptor is highly selective for PACAP and is coupled to the activation of both adenylate cyclase and phospholipase C (Deutsch and Sun, 1992; Spengler et al., 1993). By RT-PCR and in situ hybridization, SCG neurons have recently been shown to express the mRNA encoding this receptor (May and Braas, 1995; Nogi et al., 1997). VIP and PACAP bind with similar affinities to two other receptors known as the VIP1-PACAP and the VIP2-PACAP receptors. The first of these receptors is coupled only to the activation of adenylate cyclase (Ishihara et al., 1992), whereas the second can activate either adenylate cyclase or phospholipase C (Inagaki et al., 1994). Low levels of mRNA for the VIP2-PACAP receptor are present in cultured sympathetic the VIP2-PACAP (V. May, personal communication).

Although our data are consistent with the fact that VIP stimulates VIP expression via cAMP, we cannot rule out the participation of other signaling mechanisms. For example, VIP expression can also be stimulated in neuroblastoma cells by phorbol esters either through a selective phorbol ester-response element or through the CRE (Fink et al., 1991; Hahm and Eiden, 1996). Exposure of adrenal medullary cells to VIP activates not only adenylate cyclase, but also phospholipase C (Houchi et al., 1987; Malhotra et al., 1988, 1989). In the rat SCG, VIP increases inositol phosphate turnover, although secretin does not produce such an effect (Audigier et al., 1986). An attempt to confirm that the VIP-mediated feedback on VIP expression in neuronenriched cultures is mediated through a PKA-dependent pathway using the selective PKA inhibitor KT5720 was unsuccessful be- cause of toxic effects of the inhibitor. At concentrations of KT5720 that reduced both basal and VIP-stimulated levels of VIP-PHI mRNA $(2-4 \mu \mathrm{M})$, a reduction in the number of viable cells was also observed.

VIP elevates cAMP levels not only in neurons but also in non-neuronal cells (Fig. 7). The functional consequences of the latter changes are currently unknown. One interesting possibility is that VIP might enhance LIF expression in these cells. VIP has been shown to elevate LIF expression in other cells in vitro, including osteoblasts, mast cells, and astrocytes (Marshall et al., 1993; Aloisi et al., 1994; Murphy et al., 1995; Greenfield et al., 1996; Pollock et al., 1996). Furthermore, steady-state levels of LIF mRNA expression are increased in a spontaneously immortalized Schwann cell line in response to VIP or forskolin stimulation (Nagamoto-Combs and Zigmond, 1997; K. Nagamoto-Combs, unpublished observations). Because agents that elevate cAMP also increase LIF mRNA expression in a cultured Schwann cell line (Nagamoto-Combs and Zigmond, 1997), it is possible that VIP affects LIF expression by increasing cAMP levels in nonneuronal cells and can increase neuronal expression of VIP indirectly via this mechanism. Nevertheless, the fact that VIP stimulates VIP expression in the virtual absence of non-neuronal cells indicates that VIP also acts directly on SCG neurons to alter its own expression.

In intact (i.e., unlesioned) rats, VIP-IR is present in the SCG in nerve processes and in the thoracic spinal cord in preganglionic neuronal cell bodies that project to this ganglion (Sasek and Zigmond, 1989; Baldwin et al., 1991). Ligation of the cervical sympathetic trunk near the SCG leads to a build-up of VIP-IR proximal to the ligature, suggesting that the peptide is anterogradely transported to preganglionic nerve terminals in the ganglion (Baldwin et al., 1991). Furthermore, electrical stimulation of the cervical sympathetic trunk has been shown to release a noncholinergic transmitter with postsynaptic actions like those of VIP (Ip et al., 1982, 1983). The effects of VIP reported in the present paper, together with our earlier results, raise the possibility that VIP released from preganglionic nerve terminals may induce the expression of VIP in postganglionic sympathetic neurons. An alteration of the peptidergic phenotype of sympathetic neurons as a result of increased synaptic stimulation would be of considerable interest (Zigmond et al., 1989).

An induction of VIP has been shown to occur in sympathetic neurons after axotomy, and it has been proposed that VIP functions as a neurotrophic factor under these conditions (Zigmond et al., 1996; Zigmond, 1997). Previous studies have indicated that VIP can function as an activity-dependent survival factor for spinal cord neurons in culture (Brenneman et al., 1985; Brenneman and Eiden, 1986; Brenneman and Foster, 1987). VIP also supports the survival and neurite outgrowth of sympathetic precursors in vitro (Pincus et al., 1990), and can function as an autocrine growth factor for neuroblastoma cells (O'Dorisio et al., 1992; Wollman et al., 1993). Moreover, VIP supports the survival of a small population of NGF-dependent neurons when they are deprived of NGF in culture (Tanaka and Koike, 1994). A positive feedback mechanism for VIP, as suggested by our data, would be expected to prolong the period during which VIP levels are increased and available to the damaged neurons. If VIP functions as a trophic factor for sympathetic neurons after nerve injury, increasing the time that VIP is expressed may aid in survival and regeneration of these neurons. 


\section{REFERENCES}

Aloisi F, Rosa S, Test U, Bonsi P, Russo G, Peschle C, Levi G (1994) Regulation of leukemia inhibitory factor synthesis in cultured human astrocytes. J Immunol 152:5022-5031.

Ariano MA, Briggs CA, McAfee DA (1982) Cellular localization of cyclic nucleotide changes in rat superior cervical ganglion. Cell Mol Neurobiol 2:143-156.

Audigier S, Barberis C, Jard S (1986) Vasoactive intestinal polypeptide increases inositol phospholipid breakdown in the rat superior cervical ganglion. Brain Res 376:363-367.

Baldwin C, Sasek CA, Zigmond RE (1991) Evidence that some preganglionic sympathetic neurons in the rat contain vasoactive intestinal peptide- or peptide histidine isoleucine amide-like immunoreactivities. Neuroscience 40:175-184.

Brenneman DE, Eiden LE (1986) Vasoactive intestinal peptide and electrical activity influence neuronal survival. Proc Natl Acad Sci USA 83:1159-1162.

Brenneman DE, Foster GA (1987) Structural specificity of peptides influencing neuronal survival during development. Peptides 8:687-694.

Brenneman DE, Eiden LE, Siegel RE (1985) Neurotrophic action of VIP on spinal cord cultures. Peptides 6:35-39.

Colbert RA, Balbi D, Johnson A, Bailey JA, Allen JM (1994) Vasoactive intestinal peptide stimulates neuropeptide $\mathrm{Y}$ gene expression and causes neurite extension in PC12 cells through independent mechanisms. J Neurosci 14:7141-7147.

Cramer H, Johnson DG, Hanbauer I, Silberstein ND, Kopin LJ (1973) Accumulation of adenosine $3^{\prime}, 5^{\prime}$-monophosphate induced by catecholamines in the rat superior cervical ganglion in vitro. Brain Res 53:97-104.

Deutsch PJ, Sun Y (1992) The 38-amino acid form of pituitary adenylate cyclase activating polypeptide stimulates dual signaling cascades in PC12 cells and promotes neurite outgrowth. J Biol Chem 267:5108-5113.

Eiden LE, Hotchkiss AJ (1983) Cyclic adenosine monophosphate regulates vasoactive intestinal polypeptide and enkephalin biosynthesis in cultured bovine chromaffin cells. Neuropeptides 4:1-9.

Fink JS, Verhave M, Kasper S, Tsukada T, Mandel G, Goodman RH (1988) The CGTCA sequence motif is essential for biological activity of the vasoactive intestinal peptide gene cAMP-regulated enhancer. Proc Natl Acad Sci USA 85:6662-6666.

Fink JS, Verhave M, Walton K, Mandel G, Goodman RH (1991) Cyclic AMP and phorbol ester-induced transcriptional activation are mediated by the same enhancer element in the human vasoactive intestinal peptide gene. J Biol Chem 266:3882-3887.

Fishbein VA, Coy DH, Hocart SJ, Jiang N-Y, Mrozinski Jr JE, Mantey SA, Jensen RT (1994) A chimeric VIP-PACAP analogue but not VIP pseudopeptides function as receptor antagonists. Peptides 15:95-100.

Fort P, Marty L, Piechaczyk M, el Sabrouty S, Dani C, Jeanteur P, Blanchard JM (1985) Various rat adult tissues express only one major mRNA species from the glyceraldehyde-3-phosphate-dehydrogenase multigenic family. Nucleic Acids Res 13:1431-1442.

Gilman AG, Nirenberg M (1971) Effects of catecholamines on the adenosine $3^{\prime}, 5^{\prime}$-cyclic monophosphate concentrations of clonal satellite cells of neurons. Proc Natl Acad Sci USA 68:2165-2168.

Gourlett P, Vandermeers A, Vandermeers-Piret M-C, De Neef P, Robberecht $P$ (1996) Addition of the (28-38) peptide sequence of PACAP to the VIP sequence modifies peptide selectivity and efficacy. Int J Pept Protein Res 48:391-396.

Greenfield EM, Horowitz MC, Lavish SA (1996) Stimulation by parathyroid hormone of interleukin-6 and leukemia inhibitory factor expression in osteoblasts is an immediate-early gene response induced by cAMP signal transduction. J Biol Chem 271:10984-10989.

Hahm SH, Eiden LE (1996) Tissue-specific expression of the vasoactive intestinal peptide gene requires both an upstream tissue specific element and the $5^{\prime}$ proximal cyclic AMP-responsive element. J Neurochem 67:1872-1881.

Harden TK, McCarthy KD (1982) Identification of the beta adrenergic receptor subtype on astroglia purified from rat brain. J Pharmacol Exp Ther 222:600-605.

Hawrot E, Patterson PH (1979) Long-term culture of dissociated sympathetic neurons. Methods Enzymol 58:574-584.

Hayakawa Y, Obata K, Itoh N, Yanaihara N, Okamoto H (1984) Cyclic AMP regulation of pro-vasoactive intestinal polypeptide/PHM-27 synthesis in human neuroblastoma cells. J Biol Chem 259:9207-9211.

Hökfelt T, Elfvin LG, Schultzberg M, Fuxe K, Said SI, Mutt V, Goldstein
M (1977) Immunohistochemical evidence of vasoactive intestinal polypeptide-containing neurons and nerve fibers in sympathetic ganglia. Neuroscience 2:885-896.

Hökfelt T, Fahrenkrug J, Ju G, Ceccatelli S, Tsuruo Y, Meister B, Mutt V, Rundgren M, Brodin E, Terenius L, Hulting A-L, Werner S, Björklund H, Vale W (1987) Analysis of peptide histidine-isoleucine/vasoactive intestinal polypeptide-immunoreactive neurons in the CNS with special reference to their relation to corticotropin releasing factor- and enkephalin-like immunoreactivities in the paraventricular hypothalamic nucleus. Neuroscience 23:827-857.

Houchi H, Oka M, Misbahuddin M, Morita K, Nakanishi A (1987) Stimulation by vasoactive intestinal polypeptide of catecholamine synthesis in isolate bovine adrenal chromaffin cells: possible involvement of protein kinase C. Biochem Pharmacol 36:1551-1554.

Hyatt-Sachs H, Schreiber RC, Bennett TA, Zigmond RE (1993) Phenotypic plasticity in adult sympathetic ganglia in vivo: effects of deafferentation and axotomy on the expression of vasoactive intestinal peptide. J Neurosci 13:1642-1653.

Inagaki N, Yoshida H, Mizuta M, Mizuno N, Fujii Y, Gonoi T, Miyazaki JI, Seino S (1994) Cloning and functional characterization of a third pituitary adenylate cyclase-activating polypeptide receptor subtype expressed in insulin-secreting cells. Proc Natl Acad Sci USA 91:2679-2683.

Ip NY, Ho CK, Zigmond RE (1982) Secretin and vasoactive intestinal peptide acutely increase tyrosine 3-monooxygenase activity in the rat superior cervical ganglion. Proc Natl Acad Sci USA 79:7566-7569.

Ip NY, Perlman RL, Zigmond RE (1983) Acute trans-synaptic regulation of tyrosine 3-monooxygenase activity in the superior cervical ganglion: Evidence for both cholinergic and noncholinergic mechanisms. Proc Natl Acad Sci USA 80:2081-2085.

Ip NY, Baldwin C, Zigmond RE (1985) Regulation of the concentration of adenosine $3{ }^{\prime}, 5^{\prime}$-cyclic monophosphate and the activity of tyrosine hydroxylase in the rat superior cervical ganglion by three neuropeptides of the secretin family. J Neurosci 5:1947-1954.

Ishihara T, Shigemoto R, Mori K, Takahashi K, Nagata S (1992) Functional expression and tissue distribution of a novel receptor for vasoactive intestinal peptide. Neuron 8:811-819.

Itoh N, Obata K, Yanaihara N, Okamoto H (1983) Human preprovasoactive intestinal polypeptide contains a novel PHI-27-like peptide, PHM-27. Nature 304:547-549.

Malhotra RK, Wakade TD, Wakade AR (1988) Vasoactive intestinal peptide and muscarine mobilize intracellular $\mathrm{Ca}^{2+}$ through breakdown of phosphoinositides to induce catecholamine secretion. J Biol Chem 263:2123-2126.

Malhotra RK, Wakade TD, Wakade AR (1989) Cross-communication between acetylcholine and VIP in controlling catecholamine secretion by affecting cAMP, inositol triphosphate, protein kinase $\mathrm{C}$, and calcium in rat adrenal medulla. J Neurosci 9:4150-4157.

Marshall JS, Gauldie J, Nielson L, Bienenstock J (1993) Leukemia inhibitory factor production by rat mast cells. Eur J Immunol 23:2116-2120.

May V, Braas KM (1995) Pituitary adenylate cyclase-activating polypeptide (PACAP) regulation of sympathetic neuron neuropeptide $\mathrm{Y}$ and catecholamine expression. J Neurochem 65:978-987.

May V, Brandenburg CA, Braas KM (1996) Axotomy and decentralization regulate pituitary adenylate cyclase activating polypeptide (PACAP) expression in rat superior cervical ganglion. Soc Neurosci Abstr 22:1998.

Mohney RP, Siegel RE, Zigmond RE (1994) Galanin and vasoactive intestinal peptide messenger RNAs increase following axotomy of adult sympathetic neurons. J Neurobiol 25:108-118.

Mulderry PK (1993) Synergistic regulation of vasoactive intestinal polypeptide expression by cyclic AMP and calcium in newborn but not adult rat sensory neurons in culture. Neuroscience 53:229-238.

Murphy Jr GM, Song Y, Ong E, Lee YL, Schmidt KG, Bocchini V, Eng LF (1995) Leukemia inhibitory factor mRNA is expressed in cortical astrocyte cultures but not in an immortalized microglial cell line. Neurosci Lett 184:48-51.

Nagamoto-Combs K, Zigmond RE (1997) Expression of leukemia inhibitory factor in a Schwann cell line is regulated with distinct time courses by different second messenger pathways. Soc Neurosci Abstr 23:884.

Nagata Y, Ando M, Miwa M, Kato K (1984) Effects of various forms of stimulation on the content of enolase isozymes and S-100 protein in 
superior cervical sympathetic ganglia excised from rats. J Neurochem 43:1205-1212.

Nogi H, Hashimoto H, Hagihara N, Shimada S, Yamamoto K, Matsuda T, Tohyama M, Baba A (1997) Distribution of mRNAs for pituitary adenylate cyclase-activating polypeptide (PACAP), PACAP receptor, vasoactive intestinal polypeptide (VIP), and VIP receptors in the rat superior cervical ganglion. Neurosci Lett 227:37-40.

O’Dorisio MS, Fleshman DJ, Qualman SJ, O’Dorisio TM (1992) Vasoactive intestinal peptide: autocrine growth factor in neuroblastoma. Regul Pept 37:213-226.

Ohsawa K, Hayakawa Y, Nishiawa M, Yamagami T, Yamamoto H, Yanaihara N, Okamoto H (1985) Synergistic stimulation of VIP/ PHM-27 gene expression by cyclic AMP and phorbol esters in human neuroblastoma cells. Biochem Biophys Res Commun 132:885-891.

Otten U, Mueller RA, Oesch F, Thoenen H (1974) Location of an isoproterenol-responsive cyclic AMP pool in adrenergic nerve cell bodies and its relationship to tyrosine 3-monooxygenase induction. Proc Natl Acad Sci USA 71:2217-2221.

Pincus DW, DiCicco-Bloom EM, Black IB (1990) Vasoactive intestinal peptide regulates mitosis, differentiation, and survival of cultured sympathetic neuroblasts. Nature 343:564-567.

Pollock JH, Blaha MJ, Lavish SA, Steveson S, Greenfield EM (1996) In vivo demonstration that parathyroid hormone and parathyroid hormone-related protein stimulate expression by osteoblasts of interleukin-6 and leukemia inhibitory factor. J Bone Miner Res 11:754-759.

Rao MS, Escary J, Sun Y, Perreau J, Patterson PH, Zigmond RE, Brulet P, Landis SC (1993a) Leukemia inhibitory factor mediates an injury response but not a target-mediated developmental transmitter switch in sympathetic neurons. Neuron 11:1175-1185.

Rao MS, Sun Y, Vaidyanathan U, Landis SC, Zigmond RE (1993b) Regulation of substance $\mathrm{P}$ is similar to that of vasoactive intestinal peptide after axotomy or explantation of the rat superior cervical ganglion. J Neurobiol 24:571-580.

Roskoski Jr R, White L, Knowlton R, Roskoski LM (1989) Regulation of tyrosine hydroxylase activity in rat PC12 cells by neuropeptides of the secretin family. Mol Pharmacol 36:925-931.

Rougon G, Noble M, Mudge AW (1983) Neuropeptides modulate the $\beta$-adrenergic response of purified astrocytes in vitro. Nature 305:715-717.

Sakimura K, Kushiya E, Ogura A, Kudo Y, Katagiri T, Takahashi Y (1995) Upstream and intron regulatory regions for expression of the rat neuron-specific enolase gene. Mol Brain Res 28:19-28.

Sasek CA, Zigmond RE (1989) Localization of vasoactive intestinal peptide-and peptide histidine isoleucine amide-like immunoreactivities in the rat superior cervical ganglion and its nerve trunks. J Comp Neurol 280:522-532.

Schwarzschild MA, Vale W, Corigliano-Murphy AC, Pisano JJ, Ip NY, Zigmond RE (1989) Activation on tyrosine hydroxylase by peptides of the secretin-glucagon family: structure-function studies. Neuroscience 13:159-167.

Segerson TP, Lam KS, Cacicedo L, Minamitani N, Fink JS, Lechan RM, Reichlin S (1989) Thyroid hormone regulates vasoactive intestinal peptide (VIP) mRNA levels in the rat anterior pituitary gland. Endocrinology 125:2221-2223.

Spengler D, Waeber C, Pantaloni C, Holsboer F, Bockaert J, Seeburg PH, Journot L (1993) Differential signal transduction by five splice variants of the PACAP receptor. Nature 365:170-175.

Sun Y, Zigmond RE (1996) Involvement of leukemia inhibitory factor in the increases in galanin and vasoactive intestinal peptide mRNA and the decreases in neuropeptide $\mathrm{Y}$ and tyrosine hydroxylase mRNA in sympathetic neurons after axotomy. J Neurochem 67:1751-1760.

Sun Y, Rao MS, Landis SC, Zigmond RE (1992) Depolarization increases vasoactive intestinal peptide- and substance P-like immunoreactivities in cultured neonatal and adult sympathetic neurons. J Neurosci 12:3717-3728.
Sun Y, Rao MS, Zigmond RE, Landis SC (1994) Regulation of vasoactive intestinal peptide expression in sympathetic neurons in culture and after axotomy: The role of cholinergic differentiation factor/leukemia inhibitory factor. J Neurobiol 25:415-430.

Sun Y, Landis SC, Zigmond RE (1996) Signals triggering the induction of leukemia inhibitory factor in sympathetic superior cervical ganglia and their nerve trunks after axonal injury. Mol Cell Neurosci 7:152-163.

Symes A, Lewis S, Corpus L, Rajan P, Hyman SE, Fink JS (1994) STAT proteins participate in the regulation of the vasoactive intestinal peptide gene by the ciliary neurotrophic factor family of cytokines. Mol Endocrinol 8:1750-1763.

Symes AJ, Rajan P, Corpus L, Fink JS (1995) C/EBP-related sites in addition to a Stat site are necessary for ciliary neurotrophic factorleukemia inhibitory factor-dependent transcriptional activation by the vasoactive intestinal peptide cytokine response element. J Biol Chem 270:8068-8075.

Tanaka S, Koike T (1994) Vasoactive intestinal peptide suppresses neuronal cell death induced by nerve growth factor deprivation in rat sympathetic ganglion cells in vitro. Neuropeptides 26:103-111.

Tatemoto K, Mutt V (1981) Isolation and characterization of the intestinal peptide porcine PHI (PHI-27), a new member of the glucagonsecretin family. Proc Natl Acad Sci USA 78:6603-6607.

Tsukada T, Fink JS, Mandel G, Goodman RH (1987) Identification of a region in the human vasoactive intestinal polypeptide gene responsible for regulation by cyclic AMP. J Biol Chem 262:8743-8747.

Tsukada T, Fukushima M, Takebe H, Nakai Y (1995) Vasoactive intestinal peptide gene expression in the rat pheochromocytoma cell line PC12. Mol Cell Endocrinol 107:231-239.

Volle RL, Patterson BA (1982) Regulation of cyclic AMP accumulation in a rat sympathetic ganglion: effects of vasoactive intestinal polypeptide. J Neurochem 39:1195-1197.

Waymire JC, Craviso GL, Lichteig K, Johnston JP, Baldwin C, Zigmond RE (1991) Vasoactive intestinal peptide stimulates catecholamine biosynthesis in isolated adrenal chromaffin cells: evidence for a cyclic AMP-dependent phosphorylation and activation of tyrosine hydroxylase. J Neurochem 57:1313-1324.

Wessels-Reiker M, Basiboina R, Howlett AC, Strong R (1993) Vasoactive intestinal polypeptide-related peptides modulate tyrosine hydroxylase gene expression in PC12 cells through multiple adenylate cyclasecoupled receptors. J Neurochem 60:1018-1029.

Wollman Y, Lilling G, Goldstein MN, Fridkin M, Gozes I (1993) Vasoactive intestinal peptide: a growth promoter in neuroblastoma cells. Brain Res 624:339-341.

Yasuda T, Sobue G, Mitsuma T, Takahashi A (1988) Peptidergic and adrenergic regulation of the intracellular $3^{\prime}, 5^{\prime}$-cyclic adenosine monophosphate content in cultured rat Schwann cells. J Neurol Sci $88: 315-325$.

Zigmond RE (1997) LIF, NGF, and the cell body response to axotomy. The Neuroscientist 3:176-185.

Zigmond RE, Mackay AVP (1974) Dissociation of stimulatory and synthetic phases in the induction of tyrosine hydroxylase. Nature 247:112-113.

Zigmond RE, Schwarzschild MA, Rittenhouse AR (1989) Acute regulation of tyrosine hydroxylase by nerve activity and by neurotransmitters via phosphorylation. Annu Rev Neurosci 12:415-416.

Zigmond RE, Hyatt-Sachs H, Baldwin C, Qu XM, Sun Y, McKeon TW, Schreiber RC, Vaidyanathan U (1992) Phenotypic plasticity in adult sympathetic neurons: Changes in neuropeptide expression in organ culture. Proc Natl Acad Sci USA 89:1507-1511.

Zigmond RE, Hyatt-Sachs H, Mohney RP, Schreiber RC, Shadiack AM, Sun Y, Vaccariello SA (1996) Changes in neuropeptide phenotype after axotomy of adult peripheral neurons and the role of leukemia inhibitory factor. Perspect Dev Neurobiol 4:75-90. 